\title{
1 Geologic Storage of Hydrogen: Scaling up to Meet City Transportation
} 2 Demands

\author{
Anna S. Lord', Peter H. Kobos, David J. Borns \\ Sandia National Laboratories, PO Box 5800, Albuquerque, NM 87185-0706 \\ 1. Corresponding author. Tel: 1-505-284-5588; Fax: 1-505-844-0240 \\ E-mail address: acsnide@sandia.gov (Anna S. Lord)
}

\begin{abstract} caverns and therefore has lower costs.

Keywords:

Geologic storage

Hydrogen infrastructure

Hydrogen economy

Technology Cost Assessment
\end{abstract}

Over the last decade, there has been a growing interest in large-scale use of hydrogen in the transportation and renewable energy sectors. Relatively cost-effective storage options at scale are essential to realize the full potential of hydrogen as an energy carrier. Underground geologic storage of hydrogen could offer substantial storage cost reductions as well as buffer capacity to meet possible disruptions in supply or changing seasonal demands. Several geologic storage site options are being considered including salt caverns, depleted oil and/or gas reservoirs, aquifers, and hard rock caverns. This paper describes an economic analysis that addresses the costs entailed in developing and operating a geologic storage facility. The analysis focuses on salt caverns to illustrate potential city demand for hydrogen using geostorage options because (1) salt caverns are known to successfully contain hydrogen, and (2) there is more geotechnical certainty involved with salt storage as compared to the other three storage options. The main findings illustrate that geologic limitations rather than city demand cause a larger disparity between costs from one city to the next. For example Detroit hydrogen storage within salt caverns will cost approximately three times more than Los Angeles with its larger population. Detroit is located near thinly bedded salt formations, whereas Los Angeles has access to more massive salt formations. Los Angeles requires the development of larger and fewer

\section{Introduction}

In recent years there has been a push to focus on sustainable energy in order for the U.S. to become less reliant on fossil fuels. Hydrogen-fueled vehicles have been suggested as a feasible alternative to fossil-fuel dependence. Viable technologies exist to produce, store, and use hydrogen as a fuel for transportation. The current limiting factor for widespread adoption of hydrogen-fueled vehicles is the lack of necessary supporting infrastructrure-the challenge is in building an infrastructure that is economically feasible. The successful implementation of hydrogenfueled vehicles requires an economically viable way to produce, transport, store, and deliver the hydrogen to the consumer. This paper examines the options and economics of the storage component witin the infrastructure chain, specifically to focus on underground geologic storage. Previous analyses of the hydrogen infrastructure ([1-2], and [3]) indicate that there may be an important role for geologic storage to meet demand and reduce costs. The need, similar to fossil-energy stocks, is to buffer seasonal demands, provide continuity in case of disruption in the supply chain, and control congestion in the pipeline system.

Geologic storage is used extensively in the oil, natural gas, and compressed air energy industries. To illustrate the scale of this utilization, approximately 800 million barrels of oil [4] and 100s of billion cubic feet of natural gas [5] are stored geologically in the U.S. The basic drive for geologic storage is the sizable volume available for storage, which allows buffering of seasonal demands. Geologic storage also can provide a sizable financial asset, continuity of delivery in case of disruption in the supply chain, and control of congestion in the pipeline system [6]. 
The storage of hydrogen within the same type of facilities, currently used for natural gas, may add new operational challenges to the underground storage industry. Hydrogen is a small, light molecule that reacts with other elements and steel at high pressures and temperatures. Loss of hydrogen could occur through such reactions. The operations of existing storage facilities may need to be adapted to prevent hydrogen embrittlement of the steel infrastructure [7].

The type of rock formation under consideration for hydrogen storage will have profound effects on the physical and economic viability to utilize that site. Four types of geologic storage options were examined for this analysis. Currently salt caverns, depleted oil and gas reservoirs, and aquifers are the three main types of underground storage in use for natural gas today [8-9]. Other storage options available now and in the near future, such as lined hard rock caverns, will become more popular as the demand for natural gas storage grows, especially in regions where depleted reservoirs, aquifers, and salt deposits are not available.

There are four locations worldwide, three of which are in the United States, that store hydrogen. All four sites store hydrogen within salt caverns. However, there have been successful cases of storing both town gas $(50-60 \%$ hydrogen [10-11]) and helium (another small, light molecule [12]) within aquifers successfully, thus possibly inferring the same media may be suitable for storage of hydrogen gas. Future field tests need to be conducted to validate geological storage as an option.

To test the economic viability of specific types of geologic hydrogen storage, the Hydrogen Geological Storage Model (H2GSM) was developed by Sandia National Laboratories (SNL). Figure 1 illustrates the overarching assessment methodology and analytical framework of the H2GSM model. H2GSM is a prototype analytical framework developed to highlight the major components of a 'gate-to-gate', large-scale hydrogen storage facility (the analysis focuses on the storage infrastructure only). This model illustrates the analysis from a physical infrastructure, hydrogen flow, and cost perspective [13]. The analysis includes four storage options, namely salt caverns, depleted oil and gas reservoirs, aquifers, and hard rock caverns.

H2GSM was adapted to provide geologic storage input for Argonne National Laboratory's (ANL) Hydrogen Delivery Scenario Analysis Model (HDSAM). HDSAM is a hydrogen transport and delivery model, which includes geologic storage of gaseous hydrogen as one of the model components [14-15]. The model was developed to help determine the most cost effective hydrogen infrastructure from supply to demand. SNL was tasked to address the costs entailed in developing and operating an underground geologic storage facility within salt for various city demand scenarios [13]. The analysis focused on salt caverns because (1) salt caverns are known to successfully contain hydrogen, and (2) there is more geotechnical certainty involved with salt storage compared to the other three storage options [16]. 


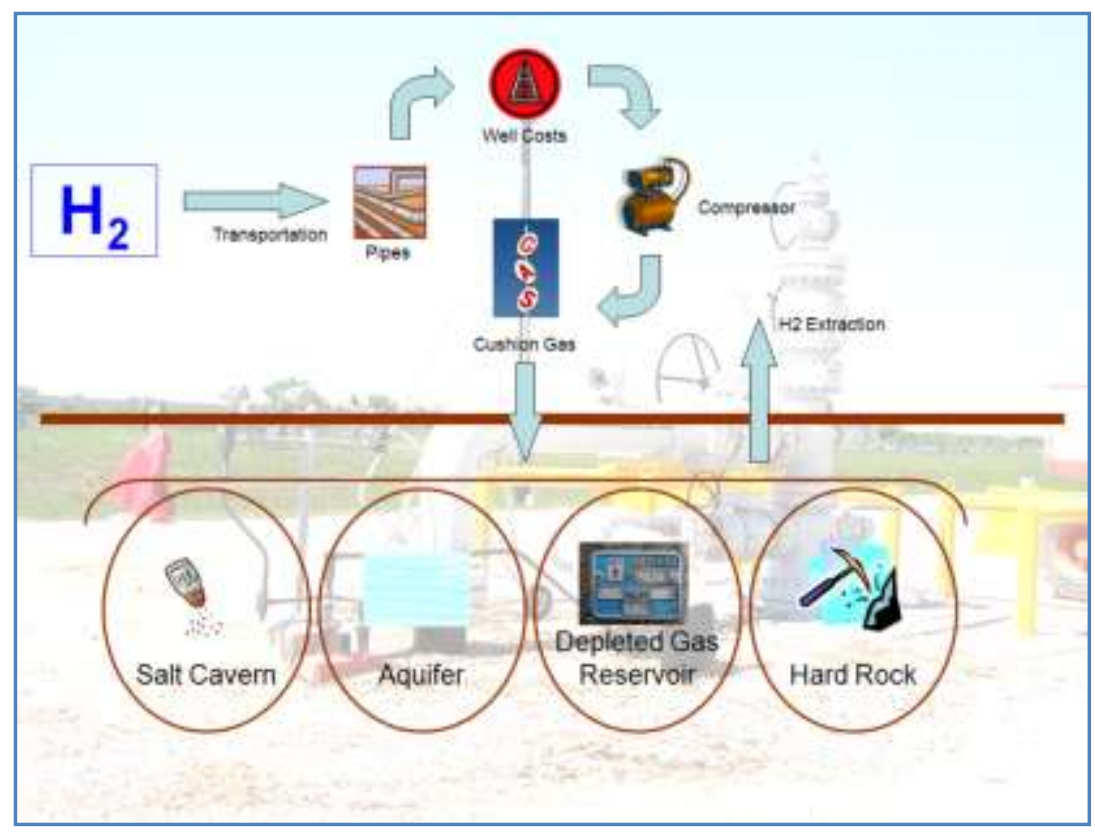

Fig 1. - The Assessment Methodology and Model Framework.

\section{Geologic Storage Options}

This section presents an overview of the various types of geologic storage currently in use for the storage of natural gas. The intent is to give an understanding of geologic storage, to describe the different storage types, and to state the advantages and disadvantages of different geologic storage types as they relate to natural gas. The four types of geologic storage examined below are 1) salt caverns, 2) depeted oil and gas reservoirs, 3) aquifers, and 4) hard rock caverns.

Underground geologic storage must have adequate capacity and containment of gas, which means it requires high porosity to store the required gas volumes. The storage formation must also have high permeability in order for gas to be injected and extracted at adequate rates. Porous reservoirs such as depleted oil and gas reservoirs and aquifers must possess an impermeable caprock along with a geologic structure to contain and trap gas. Mined caverns such as salt caverns contain gas by the impermeability of the surrounding host rock [17].

Storage of natural gas is used to meet both base and peak load requirements [8-9]. Gas stored within base load facilities is generally withdrawn once or twice a year. Peak load storage facilities are designed to meet short-term demand - gas can be withdrawn multiple times at high rates over short periods of time. Current salt cavern capacity does not come close to matching the current storage capacity of oil and/or gas reservoirs and therefore cannot be used to meet base load needs. However, salt caverns are excellent candidates for peak load cycling, and gas can be released within hours of notification at high delivery rates [8]. Natural gas stored in depleted reservoirs and aquifers is intended to meet base load needs and is generally cycled once a year during the winter season. A benefit with salt caverns is the rock has very low permeability as compared to the geologic seals of aquifers and to lesser extent depleted reservoirs. Because of the low rock permeability, salt caverns are an ideal storage option as compared to the other two and may support additional cycling throughout the year [18-19]. While aquifers may be used to meet peak load rates for natural gas, it is more uncertain for the properties of hydrogen for storage $[8,18]$. Delivery rates can be enhanced by an active water drive, using water to displace gas by filling previously gas-filled pores [7, 9]. As with salt caverns, lined hard rock caverns can be withdrawn over multiple cycles and can deliver gas at high rates [20].

The gas contained in geologic storage facilities contains both working gas and cushion gas. The cushion gas is a capital loss that is required for both gas withdrawal and to maintain storage integrity [8-9]. 


\subsection{Salt Caverns}

Salt caverns are solution mined by leaching out large cavities by injecting fresh water. Caverns can be created within salt domes or within bedded salt deposits. The salt surrounding the caverns is highly impermeable and virtually leak proof. Most likely the only avenue for gas loss is escape through leaky wells; therefore, the leak rate is likely less than $1 \%$ [8]. Locations of salt deposits within the U.S. are shown in Figure 2.

Salt domes are thick homogeneous bodies located largely along the Gulf Coast in the U.S. Due to the salt's homogeneous nature, caverns can be designed and constructed within domes that are structurally stable for requisite operating conditions above a depth of $6000 \mathrm{ft}$ [21]. Below $6000 \mathrm{ft}$ salt deformation is great due to increased pressure and temperature, and stability is difficult to maintain even for well-engineered and constructed caverns. Bedded salts used for storage are thinner and are typically found at much shallower depths than domes. Bedded salt formations alternate between salt (halite) and non-soluble beds such as dolomite, anhydrite, and shale [7, 22]. Structurally, caverns created within bedded salt formations may not be as stable as those created within salt domes due to heterogeneity of rock types present [21-22].

Creating structurally stable caverns within bedded salt is challenging. Bedded salts are thin and typically no thicker than $1000 \mathrm{ft}$ [8]. Caverns are designed to be thin and laterally extensive. Developed caverns will possibly intercept various lithologies within bedded salt formations and each layer will contain its own set of properties that affect creep rates, deformation, and slip between bedding planes [22]. Slip between bedding planes can cause gas to migrate laterally. Operating pressures will be limited to 1) the fracturing pressure of the weakest lithology within the bedded salt formation, 2) the minimum pressure to prevent roof creep and instability, and 3) below the maximum threshold pressures that could induce bedding plane slip [21].

Cushion gas requirements for salt caverns can vary substantially due to site-specific factors. Caverns can be operated under variable or constant pressures [7]. Under variable pressures, approximately $1 / 3$ of the cavern volume will contain cushion gas [23]. As working gas is withdrawn, the pressure decreases and the amount of cushion gas needed is based on the minimum pressure needed to prevent salt creep which compromises cavern integrity [7, 24 and 25]. Caverns operated under constant pressure are injected with saturated brine while withdrawing gas in order to maintain a constant pressure and cavern stability. Cushion gas is not needed under these operating conditions [7, 26].

\section{$2.2 \quad$ Depleted Oil and Gas Reservoirs}

Depleted gas and oil reservoirs have been the most prominent and commonly used reservoir for natural gas storage to date. Depleted reservoirs are old gas and oil fields, located thousands of feet underground, where most of the recoverable product has been extracted. Locations of the current U.S. oil and gas fields are displayed in Figure 2. Generally, the reservoirs are easy to develop, operate, and maintain due to the existing infrastructure $[7,8]$.

Geologically, the reservoirs have proven capable of holding gas since the reservoirs once trapped hydrocarbons that migrated up from the underlying source rock. However, some reasons for caution should be noted. In a few instances, reservoirs that once held gas actually continuously lost gas over geologic time up to the time of production. In other cases loss of gas occurred until the pressure dropped below the caprock breakthough pressure - the pressure required for gas to displace capillary water. In this instance loss of stored natural gas would occur once operating pressure was increased [7].

To function as a good gas storage container, the reservoir must have successful traps to seal the gas within the reservoir, sufficiently high permeability to meet operational flow needs, and sufficient porosity (coupled with reservoir volume) to meet the storage requirements. Traps that successfully contain gas are either structural, such as an anticline, or stratigraphic, such as an impermeable layer, e.g. caprock [7].

To maintain reservoir pressure and adequate withdrawal rates, $50 \%$ of the reservoir volume must contain cushion gas. However, once a producing reservoir is abandoned, the reservoir will still contain quantities of gas and/or oil and water. The abandoned natural gas can be used toward the cushion gas requirement [7-8]. 
In reservoirs where the existing natural gas quantity is not adequate to meet cushion gas needs, and additional gas must be injected to maintain appropriate pressure needs, the cushion gas injected is a capital loss. Aside from the loss of gas as cushion gas (i.e., gas is unrecoverable), the most likely path for gas to escape is through leaky wells. Other, most likely, insignificant losses of gas can occur through the caprock, dissolution into connate water, diffusion into the surrounding groundwater, fingering of gas with surrounding reservoir water and contamination with pre-existing hydrocarbons [7, 27]].

\subsection{Aquifers}

In regions where depleted reservoirs are not available (see Figure 2), such as the Midwestern United States, aquifers can be developed for natural gas storage. Aquifers are water-bearing porous rocks, such as sandstone, that operationally would be located thousands of feet underground [9, 23]. A suitable aquifer for storage may have geology similar to depleted gas reservoirs. The potential reservoir must have ample porosity and permeability with an existing formation pressure and large reservoir capacity.

Aquifers are often more expensive to develop than depleted reservoirs due to uncertain geology and lack of infrastructure. Geologic characteristics are not well known and data must be acquired to determine that the formation can trap and seal in gas [8,23]. Ideal gas traps are structural highs such as anticlines, with impermeable caprock, and sufficient surrounding hydrostatic and threshold pressures [7]. Additional expenses will include the construction of the above ground infrastructure since equipment such as wells, pipelines, and injection systems need to be constructed [28]. Additionally, a system must be emplaced that will dehydrate gas [7].

Cushion gas requirements for aquifers are greater than those for depleted reservoirs, due to the fact that there is no naturally occurring gas present to offset the total volume needs. The amount of cushion gas required may be as high as $80 \%$ of the total reservoir volume [8, 23 and 29]. Unlike depleted reservoirs, aquifers do not contain existing naturally occurring gas to offset the cushion gas needs.

As with depleted reservoirs, loss of gas is inevitable. In aquifers that must use cushion gas to maintain adequate pressure and withdrawal rates, cushion gas is a capital loss. Extraction of cushion gas may damage the reservoir formation, but more likely will be trapped if reservoir heterogeneity is high and within pores where gas cannot escape capillary pressure. The most common loss of gas is through leaky wells. Smaller and usually negligible gas losses occur through caprock, by dissolution into connate water and diffusion into the surrounding groundwater. Fingering between gas and water can cause the gas to travel down structure and become unrecoverable [7, 27].

\subsection{Hard Rock Cavern}

In regions where salt or porous sandstone are absent, a newly tested storage alternative may exist. Recently, technology has been explored in the excavation of caverns in hard rock and encasing those caverns, in their entirety, with steel or plastic liners. The lining acts as an impervious layer and will completely contain the gas. Caverns designed in this manner will also be operated at much higher pressures than unlined hard rock caverns, which may not be completely impervious [20].

Development of a lined cavern consists of excavating into an igneous or metamorphic rock and constructing a layer of concrete between that rock and the lining that is impermeable and will contain the stored gas [17, 20]. The host rock must be able to withstand and absorb the pressure load. The magnitude of the rock deformation will ultimately contribute to the strain of the lining [20]. The concrete layer is designed to transfer the pressure load from the liner to the surrounding rock as well as provide a smooth surface to adhere the lining. The lining must be gas tight and chemically resistant. The lining is not designed to carry any load but should be able to resist the small elastic and plastic deformation caused by the gas pressure upon the concrete backing transmitted to the rock face [20, 30]. Liners can either be created out of stainless steel or polypropylene plastic.

Since hard rock caverns are structurally stable, the need for cushion gas is minimal. In addition, a groundwater drainage system is emplaced around the perimeter of the cavern to reduce the hydrostatic pressure drive against the lining during depressurization of the cavern [20]. 

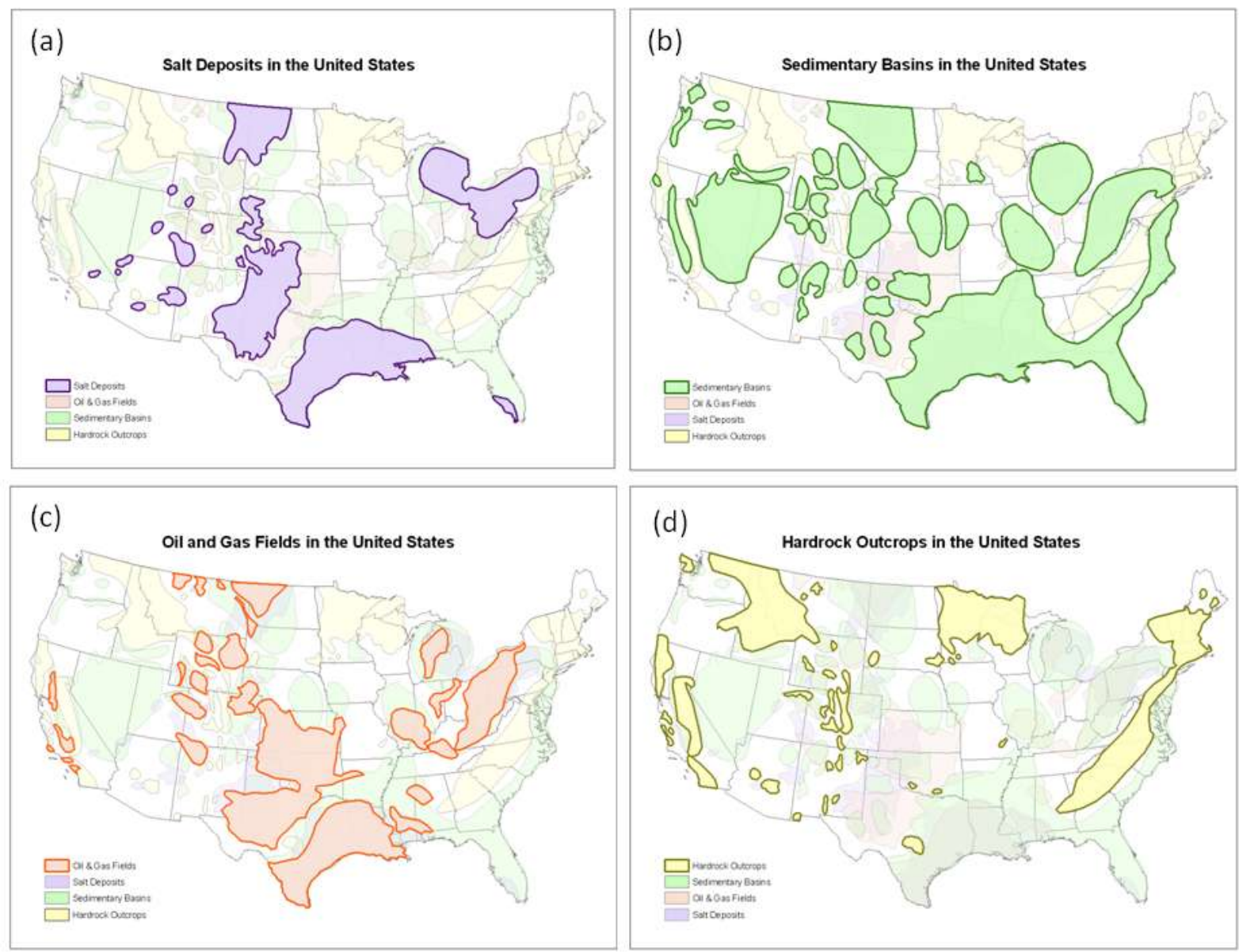

Fig. 2 - Geologic maps of the United States displaying the location of major formations for (1) salt deposits, (2) sedimentary basins, (3) major oil and gas fields, and (4) hard rock outcrops. Maps adapted from the following sources; (a) [7, 31]; (b) [7]; (c) [32]; (d) [33].

\section{The Hydrogen Geologic Storage Model}

The Hydrogen Geologic Storage Model (H2GSM) is an analytical framework developed to highlight the major components of a 'gate-to-gate' (i.e., storage infrastructure only), large-scale hydrogen storage facility. The economic analysis is designed to provide a cost comparison between four types of underground storage, namely salt caverns, depleted oil and gas reservoirs, aquifers, and hard rock caverns. The study used parameters collected from the literature and other known examples when possible. The H2GSM model has two overarching core components: the geologic storage module and the economic systems module. The city-specific demands, relying soley on storage within salt caverns, are then developed from these modules.

\subsection{Methodology}

\subsubsection{Modeling Reservoir Characteristics:}

The geologic storage model builds from several key storage parameters used for salt cavern, hard rock, depleted oil and gas reservoirs, and aquifers. To begin developing a geologic storage cost model for hydrogen, the key geologic performance parameters were developed or adapted from previous analyses to help develop a transparent cost analysis. Table 1 illustrates the salient storage characteristics used in the cost analysis assuming a 10\% market penetration of a city population similar in size to Houston, TX. 
Table 1. Geologic Site Design Characteristics.

\begin{tabular}{|l|l|l|l|l|}
\hline $\begin{array}{l}\text { Geologic Storage Site Design } \\
\text { Characteristics }\end{array}$ & Salt Cavern & $\begin{array}{l}\text { Depleted Oil \& } \\
\text { Gas Reservoir }\end{array}$ & Hard Rock & Aquifer \\
\hline Formation Pressure (Pa) & $1.3789 \times 10^{7 *}$ & $1.3755 \times 10^{7}$ & $1.3789 \times 10^{7}$ & $1.3755 \times 10^{7}$ \\
\hline Void Volume $\left.\mathbf{( m}^{\mathbf{3}}\right)$ & 580,000 & 676,941 & 580,000 & 676,941 \\
\hline Formation Temp. $(\mathbf{K})$ & $310.9 * *$ & 315.1 & 310.9 & 315.1 \\
\hline Well Depth (m) & 1158 & 1403 & 1158 & 1403 \\
\hline Working Gas (tonnes $\left.\mathbf{H}_{\mathbf{2}}\right)$ & 1,912 & 1,912 & 1,912 & 1,912 \\
\hline $\begin{array}{l}\text { Cushion Gas percent of Total Volume } \\
(\%)\end{array}$ & 30 & 50 & 30 & 50 \\
\hline Cushion Gas (tonnes $\left.\mathbf{H}_{\mathbf{2}}\right)$ & 574 & 956 & 574 & 956 \\
\hline Total $\mathbf{H}_{\mathbf{2}}$ Stored on site (tonnes $\left.\mathbf{H}_{\mathbf{2}}\right)$ & 2,486 & 2,868 & 2,486 & 2,868 \\
\hline
\end{tabular}

* Assumed to be operating pressure. ** Assumed to be gas temperature. Note: Values represent an example of demand for a city the size of Houston for illustration.

The salt cavern and hard rock cavern examples were adapted from the ConocoPhillips salt cavern, which currently stores hydrogen in Texas [16]. For the depleted oil and gas reservoir and the aquifer example, the geologic parameters used were adapted from NatCarb (2008) [34] and based on the Yeso Formation within the Estancia Basin in New Mexico. Cushion gas to working gas ratios were extracted from a 2004 report by the Federal Energy Regulatory Commission [29]. The depleted oil and gas reservoirs and aquifers require higher percentages of cushion gas to keep the formation pressure high enough for successful operations [8, 23 and 29]. An aquifer system needs cushion gas volumes between 50 and $80 \%$ of the total volume depending on the nature of the formation [23, 29].

The calculated mass of hydrogen available to use stored per geologic type $\left(H_{2} a\right)$ can be calculated, using Eq. (1) by subtracting the cushion gas ( $\mathrm{cg}$ ) requirements, shown in Eq. (2) from the potential kilograms $(\mathrm{kg})$ of $\mathrm{H}_{2}\left(\mathrm{kgH}_{2}\right)$ stored per geologic type, where (i) represents the geologic type (salt cavern, depleted oil and gas reservoir, saline aquifer, hard rock cavern). Additionally, Eq. (3) shows the total $\mathrm{kg}$ of $\mathrm{H}_{2}$ stored at the site $\left(\mathrm{H}_{2} \mathrm{~T}\right)$ illustrates the general size each site must be to store all of the desired gas to use, as well as the required cushion gas.

$H_{2} a_{\mathrm{i}}=k g H_{2, \mathrm{i}}-c g_{\mathrm{i}}$

$c g_{\mathrm{i}}=k g H_{2, \mathrm{i}} * \% c g_{\mathrm{i}}$

$\mathrm{H}_{2} \mathrm{~T}=\mathrm{H}_{2} a_{\mathrm{i}}+\mathrm{cg}_{\mathrm{i}}$

\subsubsection{Modeling Infrastructure and Cost Components:}

Building on the geologic parameters listed in Table 1, a site-specific cost analysis was develop for each storage type. Table 2 illustrates all of the infrastructure design and cost elements of the analysis by listing the cushion gas, site preparation, compressor, pipelines and well costs. With information, a more complete total capital cost and levelized capital and $\mathrm{H}_{2}$ system's cost were developed. 
Table 2. Geologic Site Design-Specific Cost Analysis Assumptions.

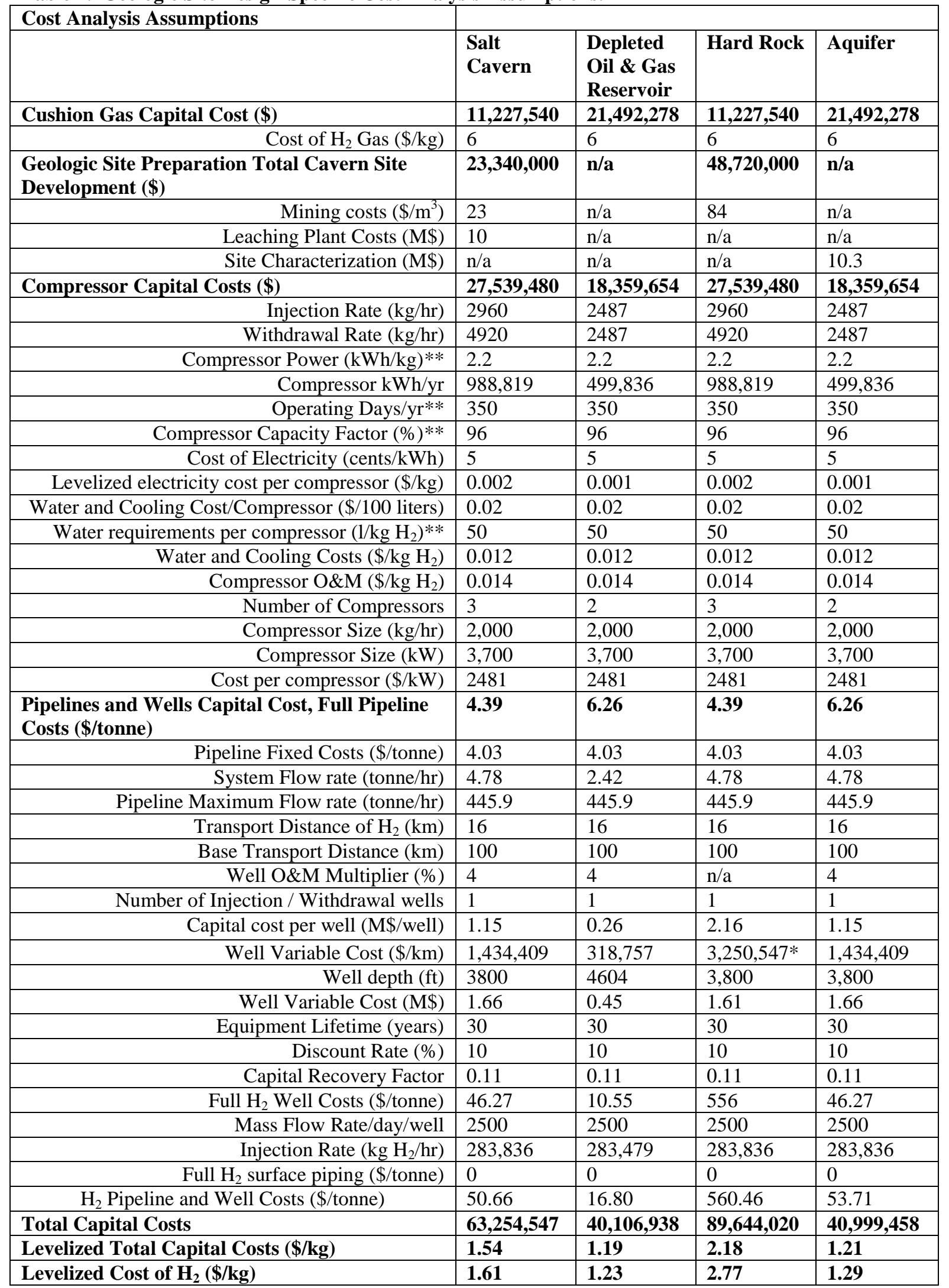


** Adapted from Amos, 1998 [36]; Capacity Factor developed from listed compressor operating 350 days per year / 365 calander days per year.

*** Adapted from Ogden, 2002 and refined in Williams, 2002.

\subsubsection{Geologic Site Cost Analysis Equations and Discussions:}

The cost analysis develops both the capital costs, and the operations and maintenanece (O\&M) costs for the geologic site, compressors, cushion gas, and wells and pipelines. The equations listed correspond to the values presented in Tables 1 and 2 .

\subsubsection{Geologic Formation Site Preparation Costs:}

The economics module calculates total capital cost $\left(T C C_{\mathrm{i}}\right)$ based on the geologic formations's capital cost $\left(\$ g f c c_{\mathrm{i}}\right)$, the compressor capital costs $(\$ c c c)$, and the fixed cost of the wells $\left(\$ w f c_{i}\right)$ specific to each type of geologic site.

Following the format presented in Table 2, the $\$ g f c c_{i}$ develops as follows:

$\$ g f c c_{i}=\left(v v_{i}^{*} m c_{i}\right)+l p c_{i}+s c_{i}$

such that the geologic site void volume $\left(v v_{i}\right)$, (i.e., $580,000 \mathrm{~m}^{3}$ for salt caverns listed in Table 1), the mining costs $\left(m c_{i}\right)$, leaching plant costs $\left(l p c_{i}\right)$, and site characterization costs $\left(s c_{\mathrm{i}}\right)$ listed in Table 2 are used. Additional, general site preparation, characterization and geoassessment costs may vary greatly by the type of site used to store $\mathrm{H}_{2}$. Recent literature on $\mathrm{CO}_{2}$ sequestration gives a sense of the great variability of these costs due to depth, pressure and formation rock type variations (McCoy and Rubin, 2009 [37]; Heath et al., 2012 [38]; Ogden and Johnson, 2010 [39]; Kobos et al., 2011 [40]). However, great caution should be used when extrapolating cost equations between $\mathrm{CO}_{2}$ storage and $\mathrm{H}_{2}$ storage in geologic formations due to the substantially less dense nature of $\mathrm{H}_{2}$ as compared to $\mathrm{CO}_{2}$ at similar temperature, pressure, and the formation's permeability and porosity characteristics. The well drilling costs may be similar at the high level, but the formation's subsurface performance differences will likely require substantial formation site screening to ensure the geologic storage option locations available for $\mathrm{H}_{2}$ may perform within the specified range of parameters (physical, chemical, engineering and cost).

\subsubsection{Compressor Costs}

Next, the compressor capital cost uses the number of compressors $(n c)$, compressor size $(c p)$, and cost per compressor $(c p c)$;

$\$ c c c=n c^{*} c p^{*} c p c$

Additionally, the compressor O\&M costs (\$com) includes the electricity (EC) as well as the water and cooling costs to run the compressors.

$\$ c o m=\left[\left(k W h c^{*} E C\right) /\left(I R^{*}(h r / y r) * \mathrm{CF}_{\mathrm{c}}\right)\right]+\left[\left(W C^{*} W R C C\right) * \chi\right]$

The compressor levelized costs are a function of the kilowatt hours required for the compressors $(k W h c)$, and the water costs associated with the compressors. The electricity costs $(E C)$, injection rate $(I R)$ the compressors' capacity factor $\left(C F_{c}\right)$, and the hours per year $(h r / y r)$ for the compressor operations drive the initial components of the $\mathrm{O} \& \mathrm{M}$ cost equation. The water and cooling costs drive the remainder of the O\&M cost equation for compressors and are a function water and cooling $(W C)$ costs in $\$ / \mathrm{kg}$, the water requirements for the compressor cooling (WRCC) that are assumed to be 50 liters/kg listed in Table 2 [36], and and the number of compressors $(\chi)$. 
For the interested reader, the kilowatt hours for a compressor with capacity of $2,487 \mathrm{~kg} / \mathrm{hr}$ [36, 41] compares well to the figure reported by others for a similar capacity of 2,960 [16, 42].

\subsubsection{Cushion Gas Costs}

Calculating the third element of the total capital cost $(\$ c g)$ uses the cost of the $\mathrm{H}_{2}\left(\$ \mathrm{H}_{2}\right)$ listed in Table 2, and the cushion gas volume listed in Table 1:

$\$ c g=\$ H_{2} * c g$

\subsubsection{Well and Surface Pipeline Costs}

The final element used in the system's total capital cost is the fixed capital cost of the wells ( $\$ w c c)$ that uses the number of operational $\mathrm{H}_{2}$ wells $\left(w_{i}\right)$, capital cost per well $\left(\$ c c w_{i}\right)$, number of brine extraction wells $\left(b e w_{i}\right)$ (applicable for salt caverns), and number of fresh water wells ( $\left.f w w_{i}\right)$ (applicable for salt cavners).

$\$ w c c=\left(w_{i} * \$ c c w_{i}\right)+\left(b e w_{\mathrm{i}} * \$ c c w_{i}\right)+\left(f w w_{i} * \$ c c w_{i}\right)$

The well O\&M costs in $\$ / \mathrm{kgH}_{2}$ ( $\$$ wom) are a based on the initial well drilling capital costs ( $\$ w d c c$ ) according to depth if and when new and additional wells may be drilled, the Capital Recovery Factor for wells $\left(C R F_{w}\right)$, the well O\&M costs multiplier $\left(O \& M_{w}\right)$, and the amount of $\mathrm{H}_{2}$ the wells are moving through the injection and withdrawl wells $\left(\mathrm{kgH}_{2, i}\right)$. This framework was adopted from Ogden et al, 2002 that outlines the capital costs for wells and surface pipelines as a function of the max flow rate of the system [1].

$\$ w o m=\left(\left(\$ w d c c * C R F_{\mathrm{w}}\right)+\left[(\$ w c c+\$ w d c) * O \& M_{w}\right]\right) / k g H_{2, i}$

The overall systems costs are updated throughout the analysis to 2007 U.S. dollars (\$US).

\subsubsection{Total Capital Cost and Levelized Cost of Hydrogen}

The economics module calculates total capital cost $\left(T C C_{i}\right)$ based on the geologic formation's capital cost $\left(\$ g f c c_{i}\right)$, the compressors' capital cost $(\$ c c c)$, the cost of the cushion gas $(\$ c g)$, and the fixed cost of the wells $\left(\$ w f c_{i}\right)$.

$T C C_{\mathrm{i}}=\$ g f c c_{\mathrm{i}}+\$ c c c_{\mathrm{i}}+\$ c g_{i}+\$ w f c_{i}$

Eq.10 is then used within the levelized total capital cost (LTCC) equation along with the capital recovery factor $(C R F)$ and capacity factor $(C F)$, along with the discount rate (10\%) and site lifetime (30 years).

$L T C C_{i}=\left(T C C_{\mathrm{i}} * C R F\right) / C F$

The levelized cost of hydrogen in US dollars per kilogram is calculated as

$L \$ H_{2, \mathrm{i}}=\left(L T C C / H_{2} a_{i}\right)+\$ c o m+\$ w o m$

\subsection{Model Results}

The results from the cost analysis for all four storage options are presented in Figure 3. According to strictly cost per kg of hydrogen stored, it appears at first the depleted oil and gas reservoir or aquifers would be the economically-attractive options. Figure 3 also displays the levelized cost of hydrogen that accounts for the 
discounted capital costs across the lifetime of the project. There may be substantial cost uncertainties when using the oil and gas reservoirs and aquifers due to the potential of $\mathrm{H}_{2}$ to migrate within and potentially out of the formation. Therefore, the salt caverns and lined hard rock caverns may be the more appropriate formation type to use to store $\mathrm{H}_{2}$ due to their lower permeability (salt or steel liners) to reduce $\mathrm{H}_{2}$ migration and allow for an operational storage facility to employ it. However, using earlier $\mathrm{CO}_{2}$ storage studies to get a sense of the geologic site characterization costs is not necessarily a good analogy due to the uncertainties within the growing field of $\mathrm{CO}_{2}$ storage or the molecule size difference (and hence transport properties) of $\mathrm{CO}_{2}$ and $\mathrm{H}_{2}$. For example, recent studies by McCoy et al. (2009) [37], Heath et al. (2012) [38] and Roach et al. 2014 [43] illustrate how greatly well costs may vary from one $\mathrm{CO}_{2}$ storage site to another based on the rock permeability, depth, thickness, and heterogeneity. In Heath et al. (2012) [38], for example, it was found the injection costs of $\mathrm{CO}_{2}$ may vary from $\$ 0.27$ to $\$ 27.3$ per tonne for two magnitudes of order difference in permeability.

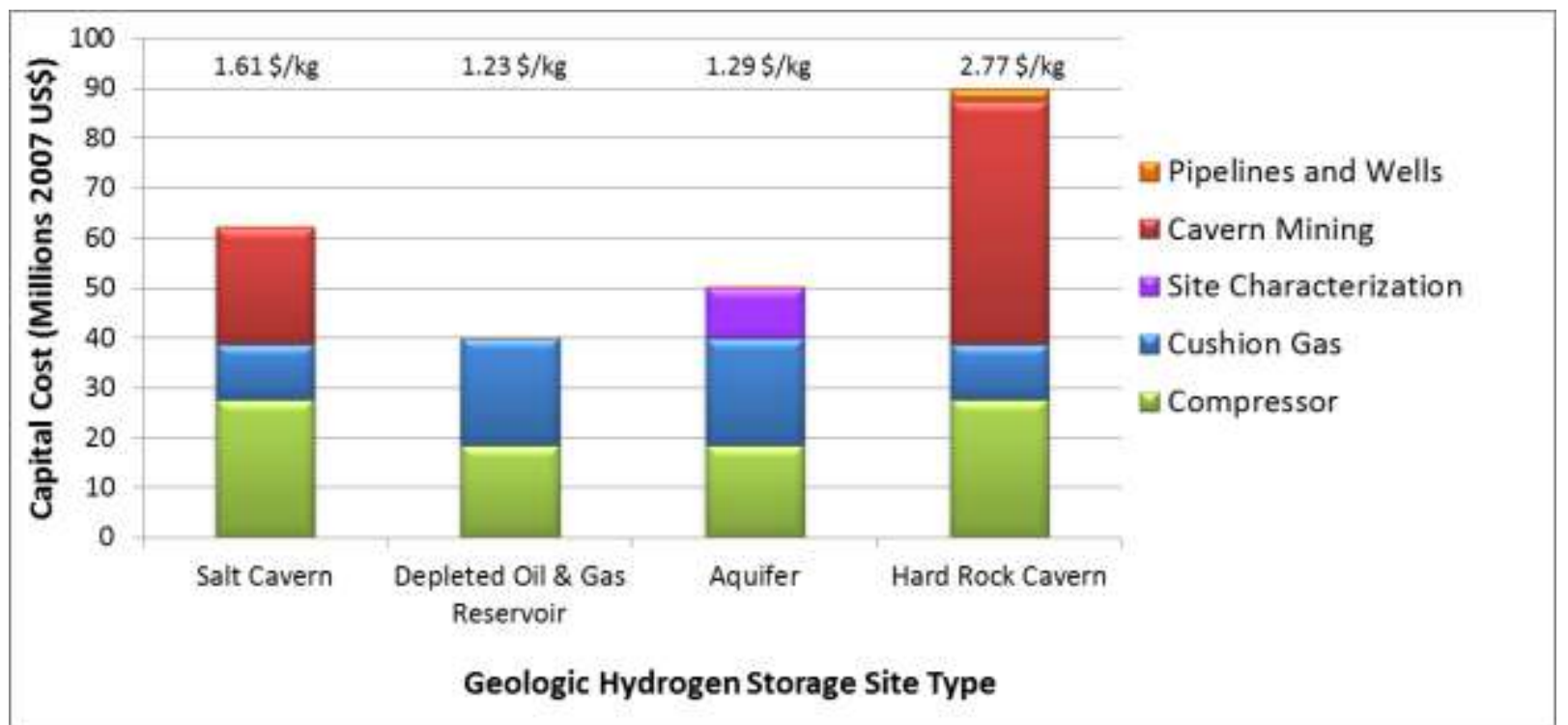

Fig. 3 - Cost Module (2007 \$US). (Note: Levelized cost of H2 (\$/kg) listed within chart; Hard Rock Cavern cost estimates do not yet include steel liners; $50 \%$ cushion gas was assumed for the aquifer scenario, where in reality the cushion gas volume could be closer to $80 \%$ of the reservoir volume and the capital costs would rise to $\$ 34$ million from \$22 million while the levelized cost remains the same at $\$ 1.29 / \mathrm{kg}$; assuming an illustrative site characterization costs of $10 \%$ of the formatin area, 1 well per $25 \mathrm{mi}^{2}$, \$3 million/well, and $\$ 100$ thousand per mi for geophysical characterizations costs (McCoy, 2008 [37]) this may add \$10.3 million to the capital costs of aquifers)

\section{4. $\mathrm{H}_{2}$ Storage Scenarios For City Demand}

To illustrate what the general scale a geologic hydrogen storage system may have to be, the analysis examined four major cities across the U.S. These cities were selected based on their geographic differences and their relative proximity to salt formations. Each city's hydrogen storage needs were based on the typical summer surge in transportation and by examining differing relative levels of potential demand [15]. Additionally, salt storage was chosen as the only storage option for salt has virtually no permeability and it is proven to contain hydrogen gas.

\subsection{Methodology}

To illustrate the H2GSM framework, the city-specific geologic storage options were developed based on the population, the summer surge in hydrogen demand, and various market penetration levels (e.g., market penetration to utilize $\mathrm{H}_{2}$ over other fuels in the transportation sector) all within their regional geological constraints (e.g., what types of salt storage options are available within a reasonable distance). 
First, the expected demand is calculated based on the population ( $p o p$ ) of the respective city (j) (Houston with 3,823,000; Detroit with 3,903,000; Pittsburgh with 1,753,000 and Los Angeles with 11,789,000 (Yang and Ogden, 2007 [44]). Based on these populations, the city-specific demand $\left(c d_{j}\right)$ is calculated using the portion of the city's transportation demand requiring $\mathrm{H}_{2}\left(p c d_{j}\right)$ using a 10\%, 25\%, and $100 \%$ set of scenarios, as well as the $\mathrm{kg}$ of $\mathrm{H}_{2}$ required per day per vehicle $(k d v)$ assumed to initially be $0.6 \mathrm{~kg} /$ day/vehicle [44] and there are 0.7 vehicles per person.

$c d_{j}=\left(p c d_{j}^{*} p o p_{j}^{*} 0.7\right) * k d v_{j}$

Based on this demand, the city's summer demand ( $s c d$ ) develops with an additional $10 \%$ increase in daily demand.

$s c d_{j}=(1+0.10) * c d_{j}$

Finally, the number of caverns is based on the summer demand per city relative to the required caverns to meet this demand. The summer cavern capacity $(s c c)$ is a function of the summer city demand, the length of the summer (120 days), and the additional summer buffer capacity percentage ( $a s b c$ ) (base case $=0$ days). Additionally, the summer cavern capacity $(s c c)$ and cushion gas $(c g)$ are added together and used to calculate the desired number of storage sites (dns) while including the storage site size ( $s s s z)$ in tonnes of $\mathrm{H}_{2}$.

$s c c=\left(\left(s c d_{j}-c d_{j}\right) * 120\right.$ days $) *(1+a s b c)$

$\operatorname{scc} g=\operatorname{scc}+c g$

$d n s=\left(\operatorname{sccg} / 10^{3}\right) / \operatorname{sss}$

\subsection{Hydrogen Model Application}

Argonne National Laboratory (ANL) developed the Hydrogen Delivery Scenario Analysis Model (HDSAM), which estimates hydrogen delivery costs as a function of hydrogen fuel cell vehicle market penetration. The model allows the user to select specific scenarios, one of which is the type of long term storage to be utilized [14]. Sandia National Laboratories (SNL) was asked to develop detailed, site-specific salt storage scenarios for three market penetration levels in four cities for input into ANL's HDSAM. The four cities were provided by ANL [15] and were Houston, Detroit, Pittsburg, and Los Angeles (L.A.). SNL's H2GSM's structure was adapted to include city demand scenarios for hydrogen storage within salt caverns.

The demand scenarios for each of the four cities use 10\%, 25\% and 100\% market penetration levels of each city's surge in demand due to summer demand by its respective population for its hydrogen transportation needs. To meet the summer demand for these cities, approximately $10 \%$ above the average daily demand for 120 days needs to be stored. Table 3 displays the mass of hydrogen required to meet the summer transportation needs for each city as both total capacity to be stored underground as well as the maximum daily production rate needed. Hydrogen summer storage needs were calculated for various market penetration levels by assuming a demand of 0.6 $\mathrm{kg} / \mathrm{day} /$ vehicle [44]. 
Table 3. City Hydrogen Demand Assessment for Storage Size Scaling.

\begin{tabular}{|c|c|c|c|c|}
\hline & Houston & Detroit & Pittsburgh & Los Angeles \\
\hline Total Population & $3,823,000$ & $3,903,000$ & $1,753,000$ & $11,789,000$ \\
\hline \multicolumn{5}{|l|}{$10 \%$} \\
\hline Population (thousand persons) & 382.3 & 390.0 & 175.0 & 1179.0 \\
\hline $\begin{array}{l}\text { Desired Production Rate } \\
\text { (tonnes } \mathrm{H}_{2} / \text { day) }\end{array}$ & 15.9 & 16.3 & 7.3 & 49.1 \\
\hline $\begin{array}{l}\text { Stored } \mathrm{H}_{2} \text { for summer demand } \\
\text { (tonnes) }{ }^{a}\end{array}$ & 1911.5 & 1951.5 & 876.5 & 5894.5 \\
\hline \multicolumn{5}{|l|}{$25 \%$} \\
\hline Population (thousand persons) & 955.8 & 975.8 & 438.3 & 2947.3 \\
\hline $\begin{array}{l}\text { Desired Production Rate } \\
\text { (tonnes } \mathrm{H}_{2} / \text { day) }\end{array}$ & 39.8 & 40.7 & 18.3 & 122.8 \\
\hline $\begin{array}{l}\text { Stored } \mathrm{H}_{2} \text { for summer demand } \\
\text { (tonnes) }{ }^{a}\end{array}$ & 4778.8 & 4878.8 & 2191.3 & 14736.3 \\
\hline \multicolumn{5}{|l|}{$100 \%$} \\
\hline Population (thousand persons) & 3823.0 & 3903.0 & 1753.0 & 11789.0 \\
\hline $\begin{array}{l}\text { Desired Production Rate } \\
\text { (tonnes } \mathrm{H}_{2} / \text { day) }\end{array}$ & 159.3 & 162.6 & 73.0 & 491.2 \\
\hline $\begin{array}{l}\text { Stored } \mathrm{H}_{2} \text { for summer demand } \\
\text { (tonnes) }\end{array}$ & 19115.0 & 19515.0 & 8765.0 & 58945.0 \\
\hline
\end{tabular}

Note: ${ }^{\text {a }}$ Summer demand represents 120 days' supply.

Each hypothetical scenario assumed hydrogen storage in caverns leached within salt deposits. It is important to note that the extent and quantity of salt available differs from one region to the next, which can radically affect the overall cost of a project. Thick salt formations (domal structures) are available within the Houston region, whereas less massive bedded salts are present within the Detroit (Michigan Basin, Salina Salt Group) and Pittsburgh (Appalachian Basin, Salina Salt Group) regions. There is no salt near Los Angeles and transportation-pipeline costs are considered for storage within Arizona salt beds. The local geology dictates the size and at what depth a cavern can be constructed.

The economic analysis employed parameters from the literature and other known examples when possible. Tables 2, 3 and 4 present the key storage conditions assumed for salt cavern storage for each city scenario. Table 4 illustrates the salt cavern site design characteristics assumed for the base case city demand scenarios. The parameters used for the salt cavern examples are adapted from the ConocoPhillips salt cavern, which currently stores hydrogen in Texas [16], as well as accounting for regional salt geology for each city. Cushion gas to working gas ratio was extracted from a 2004 report by the Federal Energy Regulatory Commission [29].

Table 4. Salt Cavern Site Design Characteristics (per cavern).

\begin{tabular}{|l|l|l|l|l|}
\hline & Houston & Detroit & Pittsburgh & Los Angeles \\
\hline Formation Pressure (psi) & $1.3789 \times 10^{7} *$ & $9.652 \times 10^{6}$ & $1.4479 \times 10^{7}$ & $1.3789 \times 10^{7}$ \\
\hline Void Volume $\left.\mathbf{~ m}^{\mathbf{3}}\right)$ & 580,000 & 99,625 & 40,000 & 580,000 \\
\hline Formation Temp. $(\mathbf{K})$ & $310.9 * *$ & 309.8 & 318 & 310.9 \\
\hline Well Depth (m) & 1158 & 667 & 940 & 1158 \\
\hline Working Gas (tonnes $\left.\mathbf{H}_{2}\right)$ & 4,367 & 527 & 310 & 4,367 \\
\hline Cushion Gas (tonnes $\left.\mathbf{H}_{2}\right)$ & 1,871 & 226 & 132 & 1,871 \\
\hline
\end{tabular}

* Assumed to be operating pressure. ** Assumed to be gas temperature. Note: Houston cavern example based on a known hydrogen cavern, in reality cavern volume can be substantially larger.

Within Table 2 are the select compressor module results for a salt cavern from the analysis framework. The base case assumptions for injection and withdrawal rates, power requirements and costs, operating and maintenance requirements and other related inputs were adapted from the literature regarding compressor operations. 
Table 5 presents a subset of the well and pipeline inputs used in the analysis. The key cost drivers for the cost of wells is the depth and number of caverns (and therefore wells) per site, and the distances between the salt formations and the cities. The modified well cost were originally based on the $\mathrm{CO}_{2}$ system's characteristics based on Ogden (2002) [1]. The Ogden model assumes $\mathrm{CO}_{2}$ at $10-15 \mathrm{MPa}$ and at $310 \mathrm{~K}$ is under supercritical conditions. Hydrogen is still a gas under the same temperature and pressure conditions, and hence has a very low density. In a similar injection system with similar volume flow rates the mass flow rate of hydrogen would be reduced by a factor of 85 .

Table 5. Well and Pipeline Cost Module.

\begin{tabular}{|l|l|l|l|l|}
\hline & Houston & Detroit & Pittsburgh & Los Angeles \\
\hline $\begin{array}{l}\text { Pipeline Transport } \\
\text { Distance }(\mathrm{km})\end{array}$ & 16 & 146 & 304 & 525 \\
\hline $\begin{array}{l}\text { Full Pipeline Costs } \\
(\$ / \text { tonne })\end{array}$ & 4.39 & 68.08 & 169.04 & 332.82 \\
\hline $\begin{array}{l}\text { Full } \mathrm{H}_{2} \text { Wells Cost } \\
(\$ / \text { tonne })\end{array}$ & 46.27 & 246.65 & 550.12 & 46.27 \\
\hline $\begin{array}{l}\mathrm{H}_{2} \text { Transportation and } \\
\text { Well Cost Total } \\
(\$ / \text { tonne })\end{array}$ & 50.66 & 314.73 & 719.15 & 382.40 \\
\hline
\end{tabular}

\section{$4.3 \quad$ Results}

The base case scenarios for each of the four cities vary greatly depending upon the total capital cost to install geologic storage to meet $10 \%, 25 \%$ and $100 \%$ market penetration of each city's summer demand for its hydrogen transportation needs. Figure 4 illustrates the capital costs, levelized costs $(\$ / \mathrm{kg})$, and number of caverns required for Houston, Detroit, Pittsburgh and L.A. at 10\%, 25\% and 100\% market penetration rates. In all scenarios, Detroit and Pittsburgh embody a larger cost profile due to their geologic limitations. The salt available for storage consists of thinner, bedded salt formations for these cities, whereas Houston and L.A. have access to thicker, more favorable salt formations. The maximum cavern size is limited for Detroit and Pittsburgh and therefore the relative size per cavern is much smaller than that for Houston or L.A. forcing the development of a greater number of caverns, which increases capital costs. This cost differentiation is also seen in the higher levelized costs $(\$ / \mathrm{kg})$ of $\mathrm{H}_{2}$ for Pittsburgh and Detroit relative to Houston and L.A. due to the lower throughput of hydrogen for each cavern developed. Additionally, L.A. has the largest population while having lower costs due to their access to more massive salt formations. While the pipeline distance is much greater, its cost is small relative to the overall system's development costs. Table 6 shows the number of caverns developed for city scenario. 


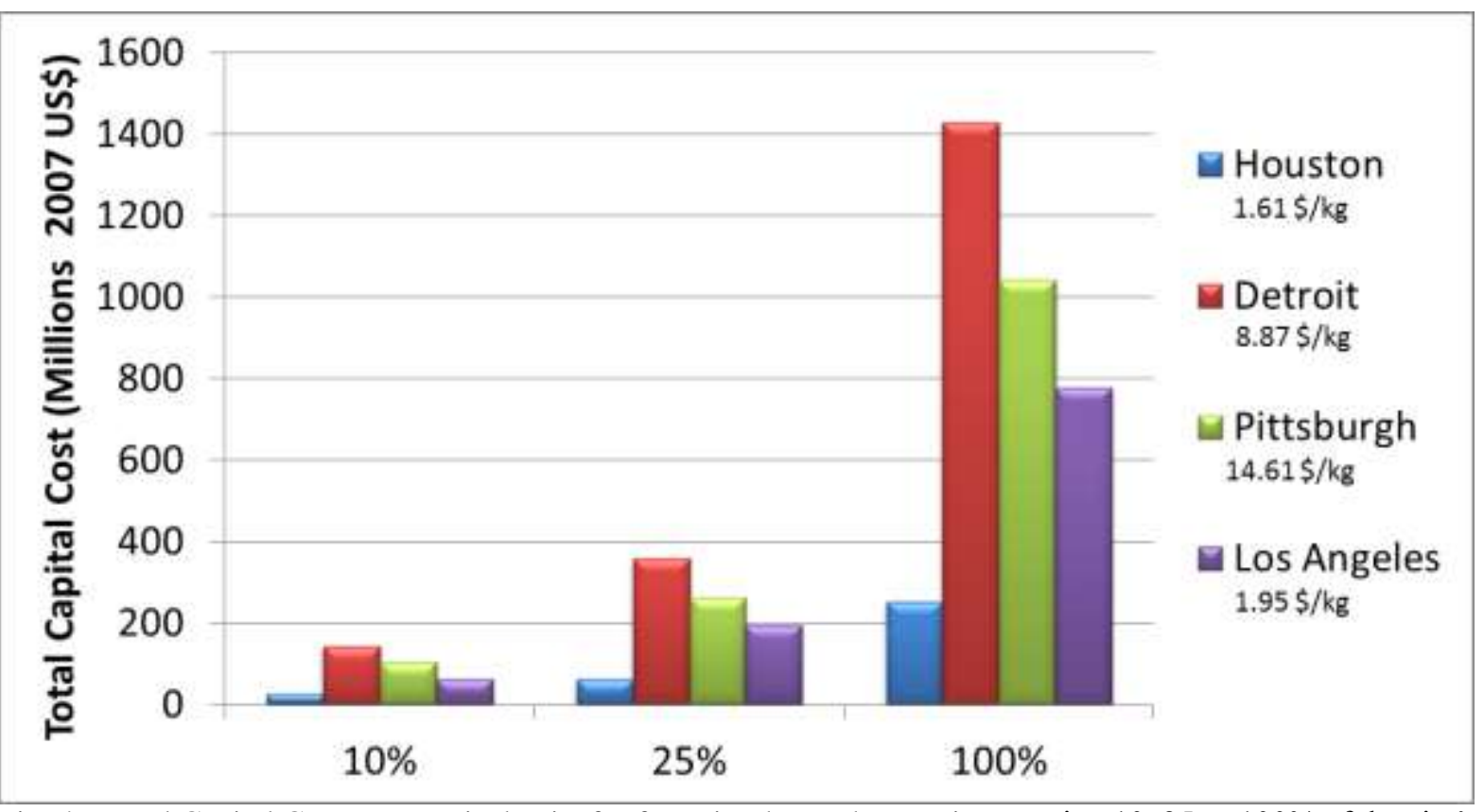

Fig. 4 - Total Capital Costs, on vertical axis, for four city demand scenarios meeting 10, 25 or $100 \%$ of the city's summer vehicle demands, horizontal axis. (Note: the levelized cost for each city is listed in legend across the three market penetration levels).

Table 6: Number of salt formation caverns required to meet city demand scenarios.

\begin{tabular}{|l|c|c|c|}
\hline \multicolumn{1}{|c|}{ City } & \multicolumn{3}{c|}{ Number of Caverns } \\
& (corresponding percentage market penetration level) \\
\hline & $\mathbf{1 0 \%}$ & $\mathbf{2 5 \%}$ & $\mathbf{1 0 0 \%}$ \\
\hline Houston & 1 & 1 & 4 \\
\hline Detroit & 3 & 7 & 26 \\
\hline Pittsburgh & 2 & 5 & 20 \\
\hline Los Angeles & 1 & 3 & 10 \\
\hline
\end{tabular}

\section{$5 \quad$ Discussion \\ 5.1 Geologic Storage Options}

Salt caverns, depleted oil and gas reservoirs, aquifers, and mined hard rock caverns may offer potential geologic options for large-scale storage of hydrogen. Salt caverns hold substantial promise due to the self-sealing nature of the salt, the ability to customize the size and often shape of the caverns, and the relatively close proximity of salt domes to the petroleum industry hubs along the Gulf Coast of the United States. Depleted oil and gas reservoirs have a known production history and thus are proven capable of holding gas. With this information, operators may have a good understanding of the potential rates of injection, withdrawal, and relative storage size of the formation. The reservoirs are easy to develop due to existing infrastructure. However, depleted oil and gas reservoirs may have a higher potential for gas loss through leaky wells (due to the age of the existing infrastructure) and residual oil or gas within the reservoir will likely cause costly hydrogen contamination issues. Aquifers represent a very large potential storage option, yet also may represent the option with the least well-understood geology and therefore may require a large number of site surveys to more fully characterize the sites, which would add time and cost to site development. Even with this characterization, there still remains some uncertainty of ensuring gas containment that may preclude the aquifers from becoming an economically-viable storage site, and therefore, financial risk involved with developing and operating these types of sites. Lastly, hard rock caverns that require mining and impermeable liners represent more fully engineered storage systems that may be developed when other storage options are not available. However, this is a relatively new technology with only one site in the world that is fully operational to store natural gas. It is important to note, however, that the existing natural gas storage options may not translate to a 
hydrogen system where substantial engineering obstacles may be encountered. Possible new operational challenges include, but are not limited to, the loss of hydrogen through chemical reactions and the occurrence of hydrogen embrittlement.

As previously described, salt caverns and hard rock caverns can be cycled multiple times per year for storage compared to depleted oil and gas reservoirs and aquifers that may only be able to be cycled once or twice yearly (aquifer delivery rates can be enhanced by an active water drive [7,9]). Including the cycle frequency in the model for the storage options may make salt caverns the most economical option by decreasing the levelized storage cost. Developing a cycling option within the cost analysis, however, may require substantial information on damage to the formations with each cycle, deformation of the site, and unforeseen geological constraints such as having sufficient size to build additional reserve caverns in proximity to the main sites in case the original site becomes damaged - all of which could affect the long term cost competitiveness of the system.

\subsection{City Demand Discussion}

A few of the key cost drivers to meet the potential $\mathrm{H}_{2}$ demand of Houston, Detroit, Pittsburgh and L.A. are their proximity to geologic salt formations, number of caverns required to meet a city's $\mathrm{H}_{2}$ demand profile, and the cost of the remaining infrastructure required to connect the cavern-supplied $\mathrm{H}_{2}$ to the demand centers. Idenfitying and developing a geotechnically-viable storage site, likely using a salt formation, will be the core technology required to develop large scale, sub-surface $\mathrm{H}_{2}$ storage. These illustrative city-based demand and cost scenarios were developed to connect a single storage site (with multiple caverns) to a single city to help with an initial, high-level assessment of the performance and cost drivers for a modest sized $\mathrm{H}_{2}$ infrastructure.

In the long run, there may be reasons to include additional cities when selecting a potential geologic salt cavern development site if a regional $\mathrm{H}_{2}$ infrastruture could be developed to help spread the costs across more than one city. Cost assessment and optimization studies indicate that for an analogous $\mathrm{CO}_{2}$ storage sink and pipeline infrastructure, there may be economies of scale and hedging strategies to reduce the overall infrastructure systems' costs by developing a combined, backbone infrastructure (pipelines or favorable geologic sites) to serve multiple customers $[43,46-48]$.

\subsection{Cost Uncertainty}

The model contains a few parameters that may have a larger uncertainty range than others. For example, the number and even size of the compressors (and other equipment) required may vary considerably depending on site-specific factors, material costs, pipeline costs, etc. Schoots et al., 2011 [39]. As shown in Figure 3, compressors represent a sizable portion of the overall capital costs. Therefore, it is important to understand the variability of these costs. The pipeline and well assessment presented here relies primarily on that in the $\mathrm{CO}_{2}$ sequestration literature and $\mathrm{H}_{2}$ pipeline costs may vary from these estimates [1, 36 and 49]. However, pipelines and wells do not represent a large fraction of the total capital cost and any changes in the cost will likely not affect the current results. Additionally, the steel liners required for the hard rock caverns are unknown at this time and their costs would be highly variable depending upon the price of steel. In an analogous example, increases in steel prices lead to increases in the cost of wind turbine installations such that while installations may have occurred, it was at a higher marginal cost than before [45]. Indeed, the price of steel constitutes between $72-82 \%$ of the capital cost of certain wind farms [50, 51]. Similar cost increases may be seen throughout these hydrogen storage cost estimates even while accounting for inflation (all costs have been adjusted to 2007 \$US). In their energy storage work, Mahlia et al., 2014 [52] and Ozarslan et al., 2012 [53] also described that cost reductions for energy storage technologies due to large scale production may not be realized due to the high costs of materials, site-specific characteristics and production capacity to build and install the technologies. Lastly, the site and case-specific number of cycles per storage option annually will also affect the levelized cost of hydrogen storage. 


\subsection{Operations Constraints}

The model is designed to create a uniform-sized cavern for each local, based on both the regional geology and literature examples. The analysis determines how many caverns will need to be developed to meet demand. For simplicity a standard sized cavern approach is utilized, where if the demand dictates the need for 1.2 caverns worth of a cavern space the program rounds the number up to 2 caverns. In reality if the geology allowed the initial cavern would be designed larger in order to cut down on capital cost or two smaller caverns would be developed to better match the demand in volume size. However, for the sake of brevity, the standard sized cavern approach allows for uniform comparisons across the various scenarios. This application of the model also considered only salt deposits as the geologic medium for storage. In reality when it is calculated that 20 or more caverns are needed for a certain city demand (e.g. Pittsburgh and Detroit at 100\% market penetration), it is most likely that the geologic deposit or space is not capable of housing that many caverns. In other words, a different storage medium (or hydrogen demand considerations) would need to be considered, such as a reservoir with a volume capacity typically several orders of magnitude larger than excavated caverns.

\subsection{Future Work}

Future work could initially focus on modeling storage cycle frequency, which would affect the overall storage system cost. This may allow a previous costly storage option such as salt caverns to be more economically attractive. The cycling analysis for salt caverns, however, may require site-specific rock properties to further understand the number of cycles the site formation can withstand without deformation. This and other parameter adjustments such as co-locating compressors to serve multiple wells instead of having a one compressor per well may decrease the overall hydrogen storage system's costs.

Additional work could also include expanding the scope of the initial analysis by developing a full, U.S.-wide hydrogen storage resource profile (e.g., a full geologic assessment) and give a representative cost assessment. This would provide the basis to develop a national geologic storage of hydrogen supply curve. By doing so, this will allow for a more complete, collaborative scale-up analysis to be developed to understand how much economicallyviable storage may be available in the U.S. This future work will help further develop the economic analysis by illustrating regions of the U.S. that may have more favorable hydrogen storage for multiple uses (e.g., storing natural gas could be a dual-fuel system for a region by both using the natural gas directly for electricity and heating as well as using the natural gas as a feedstock for removing the hydrogen to serve transportation and other demands). This may affectively increase the value of storage by serving multiple uses throughout the economy.

Lastly, possible future work effort is to consider lined caverns within sedimentary rock (i.e., soft rocks), which may possibly be easier and less expensive to mine. Lined caverns would ensure containment of the hydrogen, and may possibly be operated in a similar fashion to salt caverns.

\section{Conclusions}

Salt caverns, depleted oil and gas reservoirs, aquifers, and mined hard rock caverns may offer potential geologic options for large-scale storage of hydrogen. It is important to note, however, that existing natural gas options may not translate to a hydrogen system where substantial engineering obstacles may be encountered. Possible new operational challenges include, but not limited to, the loss of hydrogen through chemical reactions, the occurrence of hydrogen embrittlement of steel, competing uses for the materials (e.g., materials costs), right-of-way considerations for the pipelines, and an overall sense of the demand for hydrogen at the scales discussed in the analysis will all constrain the scale and scope of potential geologic storage of hydrogen.

On a strictly cost per $\mathrm{kg}$ of hydrogen stored basis, it appears that depleted oil and gas reservoirs and aquifers would be the economically-attractive options ranging from $\$ 0.04-\$ 0.06 / \mathrm{kg}$. The Salt Cavern and Hard Rock storage options have a higher levelized cost of storage ranging from $\$ 1.61-\$ 2.76 / \mathrm{kg}$. It is important to note these costs do not include the full supply chain of hydrogen production (extraction), delivery to the storage site, and other factors related to siting studies, and potential risk mitigation through measurement, monitoring and verification (MMV) while the site is operational. These costs represent the on-site costs to store hydrogen. The differences in costs between the ones listed here and those of Amos (1998) [36] reflect this. In Amos' (1998) [36] work, the 
underground storage cost is listed as \$8.80/kg (1995 \$US, and over \$10 in 2007 \$US). Their work, while similar in spirit to that presented here, also includes several different factors such as a shorter depreciation timeline, lower compressor costs and different cavern sizing and pressures. This illustrates the very real notion that both the number of parameters and the site-specific nature of geologic storage will greatly affect the system's costs.

The model was adapted to support ANL by Sandia developing several city market demand scenarios for geologic storage to potentially include in HDSAM. Cost estimates were developed for geologic storage with salt caverns to meet $10 \%, 25 \%$ and $100 \%$ market penetration of each city's surge in summer demand for its hydrogen-based transportation needs. The type and quality of salt deposits present affect the differences in costs from one city to the next. In all scenarios, Detroit and Pittsburgh embody a larger cost profile due to their geologic limitations, specifically the presence of the relatively thin salt layers, which restrict the development of large caverns. Whereas the nearest salt formation available for L.A., with the largest population, is located in a different state, but the fact that the salt deposits are so massive allow for the development of significantly larger caverns that notably reduce the cost. Otut of all for cities, Houston is the least expensive in all three scenarios due to its prime location within the Gulf Coast salt dome region which allow for the development of relatively large caverns close to Houston's metropolitan area.

\section{ACKNOWLEDGEMENTS}

The authors would like to thank Monterey Gardiner, Daniel Dedrick, and Steve Bauer for their insights. Sandia National Laboratories is a multi-program laboratory managed and operated by Sandia Corporation, a wholly owned subsidiary of Lockheed Martin Corporation, for the U.S. Department of Energy's National Nuclear Security Administration under contract DE-AC04-94AL85000.

\section{REFERENCES}

[1] Ogden, J.M., 2002, Modeling Infrastructure for a Fossil Hydrogen Energy System With $\mathrm{CO}_{2}$ Sequestration. 6th Greenhouse Gas Control Technologies Conference, Kyoto, Japan, September 30 - October 4.

[2] Williams, R.H., 2002, Toward Zero Emissions for Transportation Using Fossil Fuels, VIII Biennial Conference on Transportation, Energy, and Environmental Policy, September 2001 (Update7/15/2002).

[3] Simbeck, D. and E. Chang, 2002, Hydrogen Supply: Cost Estimate for Hydrogen Pathways - Scoping Analysis, Golden, CO: National Renewable Energy Laboratory, NREL/SR-540-32525.

[4] Department of Energy (DOE), 2011, Fossil Energy, http://fossil.energy.gov/ As of July 21, 2011.

[5] Energy Information Administration (EIA), 2011, Natural Gas Weekly Update, http://www.eia.gov/naturalgas/ As of July 21, 2011.

[6] Hirschhausen, C.v., 2008, Infrastructure, regulation, investment and security of supply: A case study of the restructured US natural gas market, Utilities Policy, 16, pp. 1-10.

[7] Foh, S., M. Novil, E. Rockar, and P. Randolph, 1979, Underground Hydrogen Storage Final Report. Brookhaven National Laboratories, Upton, NY.

[8] Natural Gas Supply Association (NGSA), Storage of Natural Gas, found at (http://www.naturalgas.org/naturalgas/storage.asp), June 27, 2007.

[9] Energy Information Administration (EIA), 2007, The Basics of Underground Natural Gas Storage, found at http://www.eia.doe.gov/pub/oil_gas/analysis_publications/storagebasics/storagebasics.html, June 29, 2007.

[10] Fasanio, G., and J.E. Molinard, 1989, Mixing in Underground Gas Storage, in Proc. NATAO Advanced Study Institute on Underground Storage of Natural Gas Theory and Practice, M.R. Tek, Ed., Ankara, Turkey, pp. 301-325.

[11] Panfilov, M., G. Gravier, and S. Fillacier, 2006, Underground Storage of H2 and H2-CO2-CH4 Mixtures, 10 ${ }^{\text {th }}$ European Conference on the Mathematics of Oil Recovery, Amsterdam, Netherlands, September 4-7.

[12] Tade, M.D., 1967, Helium Storage in Cliffside Field, The Journal of Petroleum Technology, pp. July, 1967, 885-888.

[13] Lord, A.S., Kobos, P.H., Klise, G.T. and D.J. Borns, 2011, A Life Cycle Cost Analysis Framework for Geologic Storage of Hydrogen: A User's Tool, SAND2011-6221, September.

[14] Chen, T., 2008, Hydrogen Delivery Infrastructure Options Analysis, Nexant, DOE Award Number: DE-FG36$05 \mathrm{GO} 15032$ 
[15] Elgowainy, A., 2011, Personal Communication, representative scenarios.

[16] Parks, G.D., 2007, ChevronPhillips Hydrogen Cavern Clemens Terminal, www.internationalpipelineconference.com/presentation_Files/1030_PARKS-Clemens_ReleaseFinal.ppt.zip ConocoPhillips. As of June 2007.

[17] MJMEnergy Ltd, MZINE, Gas Storage - the reasons and the means, March 2007, Gas Storage-1 Issue, found at http://www.mjmenergy.com/MZINE/2007/gs1.htm , July, 2, 2007

[18] PB-KBB Inc, 1998, Advanced Underground Gas Storage Concepts Refrigerated-Mined Cavern Storage: Final Report. PB-KBB Inc, Houston, TX.

[19] Wang, X. and M.J. Economides, 2012, Purposfully built underground natural gas storage, Journal of Natural Gas Science and Engineering, 9, pp. 130-137.

[20] Sofregaz U.S. Inc. and LRC, 1999, Commercial Potential of Natural Gas Storage in Lined Rock Caverns (LRC), Topical Report SZUS-0005 DE-AC26-97FT34348-01. Sofregaz U.S, Houston, TX, and LRC, Sweden.

[21] Bruno, M.S. and M.B. Dusseault, 2002, Geomechanical Analysis of Pressure Limits for Thin Bedded Salt Caverns. Spring 2002 Solution Mining Research Institute Technical Meeting, Banff, Alberta, Canada, April 29-30.

[22] Han, G., M.S. Bruno, K. Lao, and J. Young, 2006, Gas Storage and Operations in Single-Bedded Salt Caverns: Stability Analyses. SPE Gas Technology Symposium, Calgary, Alberta, Canada, May 15-17.

[23] Beckman, K.L., P.L. Determeyer, and E.H. Mowrey, 1995, Natural Gas Storage: Historical Development and Expected Evolution: December 1994-February 1995. GRI-95/0214. Gas Research Institute, Houston, TX, June 1995.

[24] National Energy Technology Laboratory (NETL), Transmission, Distribution, \& Refining, Natural Gas Storage, http://www.netl.doe.gov/technologies/oil-gas/TDR/Storage/Storage.html, June 27, 2007.

[25] National Energy Technology Laboratory (NETL), Oil \& Natural Gas Projects, Transmission, Distribution, \& Refining, http://www.netl.doe.gov/technologies/oil-gas/NaturalGas/Projects_n/TDS/Storage/ STOR_C_34348Commercial.html, July 2, 2007.

[26] Taylor, J.B., J.E.A. Alderson, K.M. Kalyanam, A.B. Lyle, and L.A. Phillips, 1986, Technical and Economic Assessment of Methods for the Storage of Large Quantities of Hydrogen, in Int. J. Hydrogen Energy, vol. 11, no.1, pp.5-22.

[27] Carden, P.O and L. Paterson, 1979, Physical, Chemical and Energy Aspects of Underground Hydrogen Storage, in Int. J. Hydrogen Energy, vol. 4, pp. 559-569.

[28] Walters, A.B., 1976, Technical and Environmental Aspects of Underground Hydrogen Storage in $1^{\text {st }}$ World hydrogen energy conference proceedings, vol. 2, 15p, held in Miami Beach, Florida, March 1-3.

[29] Federal Energy Regulatory Commission (FERC), 2004, Current State of and Issues Concerning Underground Natural Gas Storage, Docket No. AD04-11-000.

[30] Glamheden, R. and P. Curtis. Excavation of a cavern for high-pressure storage of natural gas. Tunnelling and Underground Space Technology. Vol. 21, 56-57, 2006.

[31] Gillhaus, A., F. Crotogino, and D. Albes, 2006, Compilation and evaluation of bedded salt cavern characteristics important to successful cavern sealing, Part 1: Worldwide bedded slat deposits and bedded salt cavern characteristics. 2003-5-SMRI. Solution Mining Research Institute Research Project Report, March 2006.

[32] Mast, R.F., D.H. Root, L.P. Williams, W.R. Beeman, and D.L. Barnett, 1998, Areas of historical oil and gas exploration and production in the conterminous United States, U.S. Geological Survey Geologic Investigations Series I-2582, scale 1: 3,750,000.

[33] Bush, J.B., 1976. Economic and Technical Feasibility Study of Compressed Air Storage. ERDA 76-76. General Electric Company, Schenectady, New York.

[34] National Carbon Sequestration Atlas (NatCarb), 2008, Estancia Yeso formation. http://www.natcarb.org/

[35] Mansure, C. and D. Blankenship, 2010, Geothermal Well Cost Update 2010, GRC Transactions, Vol. 34.

[36] Amos, W.A., 1998, Cost of Storing and Transporting Hydrogen, NETL/TP-570-25106.

[37] McCoy, S.T., 2009, Variability and Uncertainty in the Cost of Saline Formation Storage, Energy Procedia, 1, pp. 4151-4158.

[38] Heath, J.E., Kobos, P.H., Roach, J.D., Dewers, T.A. and S.A. McKenna, 2012, Geologic Heterogeneity and Economic Uncertainty of Subsurfact Carbon Dioxide Storage, SPE Economics \& Management, January.

[39] Kobos, P.H., Cappelle, M.A., Krumhans1, J., Dewers, T.A., McNemar, A. and D.J. Borns, 2011, Combining power plant water needs and carbon dioxide storage using saline formations: Implications for carbon dioxide and water management policies, International Journal of Greenhouse Gas Control, 5, pp. 899-910. 
[40] Schoots, K., Rivera-Tinoco, R., Verbong, G. and B. v.d. Zwaan, 2011, Historical variation in the capital costs of natural gas, carbon dioxide and hydrogen pipelines and implications for future infrastructure, International Journal of Greenhouse Gas Control, 5, pp. 1614-1623.

[41] Steward, D., 2010, Personal Communication, representative scenario.

[42] American Gas Association (AGA), 1996, Gas Engineering \& Operating Practices, Vol. 1, Ch. 1, Case Studies, Catalog No. XY9603C, Wharton Field, Pennsylvania National Fuel Gas Corporation.

[43] Roach, J., Heath, J.E., Kobos, P.H. and G. Klise, 2014, System-level Benefits of Extracting and Treating Saline Water from Geologic Formations during National-Scale Carbon Capture \& Storage, International Journal of Greenhouse Gas Control,25, pp. 186-197.

[44] Yang, C., and J. Ogden, 2007, Determining the lowest-cost hydrogen delivery mode, International Journal of Hydrogen Energy, 32, pp. 268-286.

[45] Oil \& Gas Journal, 2009, Special Report on Pipeline Economics, C.E. Smith (Pipeline Editor), Table 5, p. 67, Sept. 14.

[46] Johnson, N., 2012, Detailed spatial modeling of coal-based hydrogen infrastructure deployment with carbon capture and storage: methods, implications, and insights, UCD-ITS-RR-12-30, Institute of Transportation Studies, UC Davis.

[47] Kobos, P.H., Malczynski, L.A., Borns, D.J. and B.J. McPherson, Carbon Sequestration in the Southwestern United States: Using the 'String of Pearls' Model for Cost and Source-to-Sink Assessments, 27th USAEE/IAEE North American Conference, SAND2007-5153C, Houston, TX, September 16 - 19, 2007.

[48] Odgen, J. and N. Johnson, 2010, Techno-economic analysis and modeling of carbon dioxide capture and storage technologies, in: Maroto-Valer, M., (Ed.), Developments and Innovation in Carbon Dioxide Capture and Storage Technology: Carbon dioxide capture, transport and industrial application (Volume 1). Woodhead Publishing Ltd, Cambridge, UK, pp. 27-63.

[49] Parker, N., 2004, Using Natural Gas Transmission Pipeline Costs to Estimate Hydrogen Pipeline Costs, UCDITS-RR-04-35, Institute of Transportation Studies, UC Davis.

[50] Qiu, Y. and L.A. Anadon, 2011, The price of wind power in China during its expansion: Technology adoption, learning-by-doing, economies of scale, and manufacturing localization, Energy Economics, In Press.

[51] European Wind Energy Association (EWEA), 2009, Wind energy-the facts: volume 2, costs \& prices, Report of the European Wind Energy Association, p. 103.

[52] Mahali, T.M.I., Saktisahdan, T.J., Jannifar A., Hasan, M.H. and H.S.C. Matseelar, 2014, A review of available methods and development on energy storage; technology update, Renewable and Sustainable Energy Reviews, 33, pp. 532-545.

[53] Ozarslan, A., 2012, Large-scale hydrogen energy storage in salt caverns, International Journal of Hydrogen Energy, 37, pp. 14265-14277. 